morphologically and with the help of immunocytochemistry. There was no staining by antibodies CK 1 (Dako) or CAM 5.2 (Becton-Dickinson) to intracellular cytokeratin antigens. All the tumours stained positively for vimentin but not for desmin or leucocyte common antigen. The main differential diagnosis of spindle cell squamous carcinoma was excluded in each case.

\section{Comment}

Squamous cell carcinoma is a well recognised complication of venous ulceration, and basal cell carcinoma has also been reported.' Sarcomatous change has previously been considered exceptionally rare, ${ }^{2}$ and malignant fibrous histiocytoma has never been reported.

Predisposing factors to malignant fibrous histiocytoma include radiotherapy and trauma. None of our patients had a history of radiotherapy, and only one (case 3) had had a minimal injury. Malignant fibrous histiocytoma is a highly malignant neoplasm with a pronounced tendency to recur locally after excision. ${ }^{3}$ Distal and superficial tumours, however, carry a better prognosis than those in proximal sites or deeper structures. ${ }^{+}$This complication of venous ulceration is therefore potentially curable if diagnosed early. All three of our patients were probably cured. It therefore becomes even more important that malignancy should be considered by all doctors managing chronic venous ulcers and that a biopsy should be performed promptly when necessary.

1 Burns DA, Calnan CD. Basal cell epithelioma in a chronic leg ulcer. Clin Exp Dermutol 1978:3:4+3-5.

2 Nunnery EW, Lipper S, Reddick R, Kahn LB. Leiomyosarcoma arising in a chronic venous stasis ulcer. Hum Pathol 1981;12:951-3.

3 Weiss SW, Enzinger FM. Malignant fibrous histioctioma, an analysis of 200 cases. Cancer 1978;41:2250-66.

+ Kearney MM, Soule EH, Ivins JC. Malignant fibrous histiocvioma, a retrospective study of 167 cases. Cancer 1980;45:167-78.

(Accepted 20 October 1988)

\title{
Is severe bradycardia in veteran athletes an indication for a permanent pacemaker?
}

\section{University Department of Medical Cardiology, Queen Elizabeth Building, Glasgow G12 8QQ Robin J Northcote, MD, senior registrar \\ Andrew C Rankin, MD, lecturer \\ Department of Medical Cardiology, Victoria Infirmary, Glasgow G42 9TY \\ Regina Scullion, $\mathrm{MB}$, registrar \\ Department of Cardiology, Victoria Hospital, Blackpool FY3 8NR William Logan, MD, consultant}

Correspondence to: $\mathrm{Dr}$ Northcote.

Br.Med f 1989;298:231-2

\section{Robin J Northcote, Andrew C Rankin, Regina Scullion, William Logan}

Severe bradycardia may be present in athletes without symptoms who wish to continue training, and the correct way to manage these patients is uncertain.

\section{Case reports} CASE 1

A 66 year old man with 50 years' running experience presented with a non-specific anaemia. He ran between 40 and $129 \mathrm{~km}$ a week. Apart from a resting bradycardia he had no clinically detectable cardiovascular abnormality. A resting 12 lead electrocardiogram showed sinus bradycardia, first degree heart block (PR interval $=0.31$ seconds), normal ventricular axis, and voltage criteria for left ventricular hypertrophy ( $S$ wave in $V_{1}+R$ wave in $V_{s}=39 \mathrm{~mm}$ ). He exercised on a treadmill (Bruce protocol) for 16.5 minutes. By stage II he had developed ST segment depression of $1 \mathrm{~mm}$

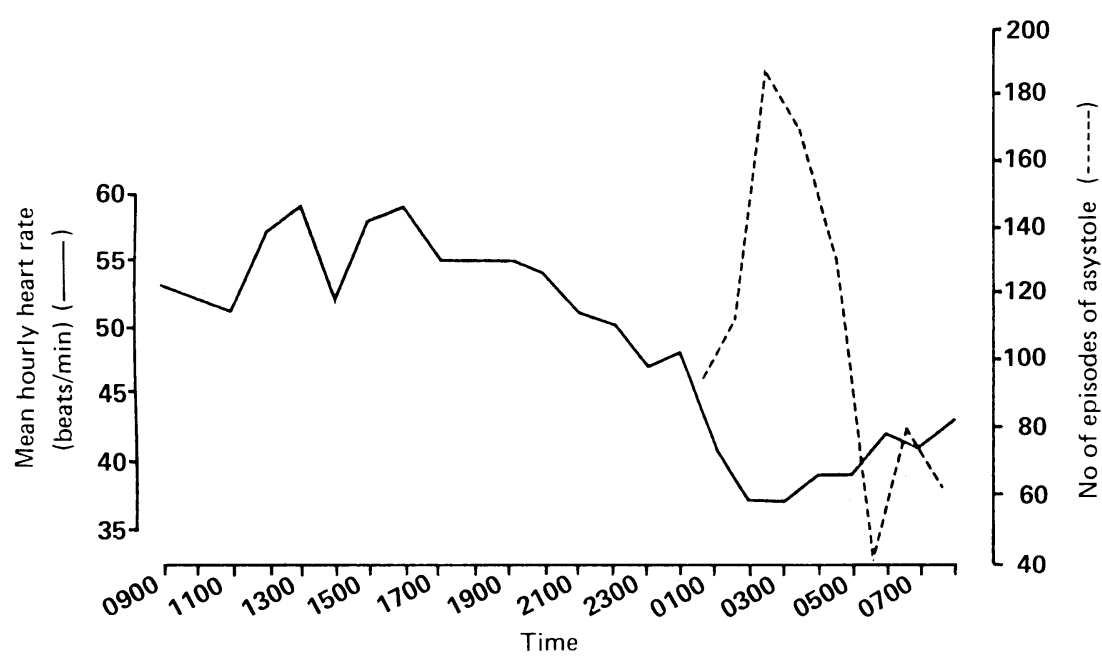

Response of heart rate over 24 hours and frequency of cardiac asystole (longer than two seconds). Note maintenance of circadian rhythm in the inferolateral leads. Ambulatory electrocardiography showed a mean heart rate over 24 hours of 49 beats/minute. His minimum heart rate was 17 beats/minute, at 0300 (figure). He had first and second degree heart block (Mobitz type II), and complete heart block occurred nocturnally. Pauses of greater than 2 seconds occurred on 846 occasions, the longest being 8.9 seconds. Subsequent monitoring in hospital showed recurrent nocturnal ventricular standstill lasting 10-12 seconds.

We implanted a dual chamber permanent pacemaker (Pacesetter AFP 283), and subsequent coronary angiograms were normal. He felt generally more energetic and noticed a considerable improvement in his racing performances.

CASE 2

A 52 year old former professional boxer who ran 11 $\mathrm{km}$ daily had risen from bed and lost consciousness. When admitted to hospital he lost consciousness again; this was associated with ventricular standstill lasting 30 seconds. He denied cardiovascular symptoms but admitted to having had episodes of lightheadedness or "muzziness" that were relieved by brisk exertion. We implanted a permanent pacemaker (Vitatron Quintech TX 915 rate responsive generator) on the basis of his history and asystolic pauses. Subsequently his symptoms stopped.

\section{Comment}

Athletes' bradycardia is ascribed to an increase in vagal tone, ${ }^{12}$ though pharmacological denervation has shown that they have a slower intrinsic heart rate independent of vagal tone. High degree atrioventricular block or prolonged ventricular pauses are rare. ${ }^{23}$ Veteran athletes may be more susceptible to bradyarrhythmias because of the decrease in heart rate that occurs with increasing age combined with the effects of many years of physical training.

The absence of underlying cardiac disease in these two patients makes it likely that the profound bradycardia with prolonged cardiac pauses was the result of lifelong endurance training. Whether such secondary bradyarrhythmias require implantation of a permanent pacemaker is uncertain. Nocturnal high degree atrioventricular block, with pauses of up to six seconds, has been reported to resolve after the intensity of physical training has been reduced. ${ }^{3}$ Pacemakers have been implanted in three young adults with prolonged sinus pauses during rapid eye movement sleep because of 
concern about possible insidious loss of neural or other bodily functions as a result of repeated nocturnal asystole. ${ }^{+}$

The frequent prolonged asystolic pauses in case 1 were considered sufficient indication for a pacemaker because of concern that the arrhythmia might progress, with the possibility of sudden death and adverse effects of chronic recurrent ventricular standstill. Whether stopping the patient from running would have successfully managed his condition is unknown, but he would have considered this to be an important deterioration in his quality of life.

Lifelong physical endurance training may result in an adaptive bradycardia and prolonged atrioventricular nodal conduction, which cannot be regarded as a purely benign physiological adaptation but may represent a pathological process causing symptoms, syncope, systemic embolism, or sudden death.' We chose to manage both patients with permanent pacemakers to maintain cardiac rhythm and allow them to continue their sporting activities. The improvement in performance in both patients would seem to support this policy.

1 Talan DA, Bauernfeind RA, Ashley WW, Kanakis C, Rosen KM. Twenty-four hour continuous ECG recordings in long distance runners. Chest 1982 82:19-24.

2 Ector $\mathrm{H}$, Verlinden $\mathrm{M}$, Vanden-Eynde $\mathrm{E}$, et al. Bradycardia, ventricular pauses, syncope and sports. Lancet 1984;ii:591-4.

3 Di Nardo-Ekery D, Abedin Z. High degree atrioventricular block in marathoner with 5-year follow-up. Am Heart $\mathcal{f}$ 1987;113:834-7.

+ Guilleminault C, Pool P, Moota J, Gillis AM. Sinus arrest during REM sleep in young adults. $N$ Engl $f$ Med 1984;311:1006-10.

Accepted 19 October 1988

\section{Dietary maladvice as a cause of hypothyroidism and short stature}

M Labib, R Gama, J Wright, V Marks, D Robins

Departments of Clinical Biochemistry and Clinical Nutrition and Paediatrics, St Luke's Hospital, Guildford, Surrey GU1

3NT

M Labib, MRCPATH, senior registrar

R Gama, MRCP, registrar

J Wright, MRCPATH, consultant

V Marks, FRCPATH, professor

D Robins, FRCP, consultant

paediatrician

Correspondence to: $\mathrm{Dr}$

Labib, department of

clinical biochemistry and

clinical nutrition.

Br.Med F 1989;298:232-3
Restrictive diets for children can be dangerous.' We describe a child who was given a restrictive diet for purported food sensitivity and presented with short stature and hypothyroidism due to dietary iodine deficiency.

\section{Case report}

A 4 year old boy was investigated for short stature. He had weighed $3200 \mathrm{~g}$ at birth ( $>25$ th centile) and had been fed cows' milk formula for six months, when solid food was introduced. When he was 2 his mother sought advice because of his poor appetite and constipation. His height and weight were below the third centile, but his rate of growth was normal. Both parents were short (father $152 \mathrm{~cm}$, mother $149 \mathrm{~cm}$ ). Despite treatment with lactulose he remained constipated, and a dietitian advised the mother to withdraw cow's milk and give him soya milk. During the next six months he developed diarrhoea and was referred by his general practitioner to a centre for "alternative therapies," where sensiti- vity to cows' milk, dairy products, goats' milk, eggs, chocolate, sugar, food additives, fish, beef, lamb, and pork was diagnosed. On advice his mother withdrew these items from his diet. During the next year his rate of growth dropped below the third centile.

The table summarises the investigations over time. On examination at 4 years 3 months his weight and height were below the third centile. Plasma electrolyte concentrations were normal, albumin concentration was $36 \mathrm{~g} / \mathrm{l}$, and radiological assessment gave a bone age of 3 years. Six weeks later results of pituitary function tests showed suboptimal growth hormone response but normal responses of cortisol, gonadotrophin, and prolactin. Basal plasma thyroid stimulating hormone concentration was raised but the response to thyrotrophin releasing hormone was normal.

Reassessment six months later showed an adequate response of growth hormone to glucagon. Plasma total and free thyroxine concentrations were low, and because the basal plasma thyroid stimulating hormone concentration was raised and the response to thyrotrophin releasing hormone exaggerated hypothyroidism was diagnosed. His autoimmune profile was normal, and thyroidal uptake of iodine- 131 was $68 \%$ at four hours (normal 11-30\%). Dietary assessment showed an average daily iodine intake of $40 \mu \mathrm{g} /$ day (recommended daily allowance $120 \mu \mathrm{g}$ ), and 24 hour urinary iodine excretion was low on two occasions $(6 \cdot 2$ and $30 \cdot 2 \mu \mathrm{g} / \mathrm{g}$ creatinine).

A normal diet including cows' milk supplemented with iodine $(40 \mu \mathrm{g} /$ day $)$ was reintroduced. After four

Results of biochemical investigations, weight, and height related to changes in diet

\begin{tabular}{|c|c|c|c|c|}
\hline Age & Treatment & Results of investigations & Height $(\mathrm{cm})$ & Weight $(\mathrm{kg})$ \\
\hline 2 Years 2 months & & & $77 \cdot 5$ & $9 \cdot 0$ \\
\hline 3 Years 0 months & Cows' milk substituted with sova milk & & $81 \cdot 3$ & $9 \cdot 9$ \\
\hline 3 Years 6 months & Restrictive diet introduced & & & \\
\hline 4 Years 3 months & & $\begin{array}{l}\text { Plasma growth hormone } 2.5 \mathrm{mU} / 1 \text { basally, } 4.5 \mathrm{mU} / 1 \text { after exercise test. Plasma insulin-like } \\
\text { growth factor- } 1100 \mathrm{U} / 1 \text {. Plasma total thyroxine } 94 \mathrm{nmol} / 1\end{array}$ & $87 \cdot 5$ & $12 \cdot 0$ \\
\hline 4 Years 5 months & & $\begin{array}{l}\text { Insulin stress test }{ }^{\star} \text { showed cortisol } 215 \text { (basal) and } 872 \text { (peak) nmol/l, growth hormone } 4 \cdot 4 \\
\text { and } 12 \cdot 5 \mathrm{mU} / 1 \text {, prolactin } 248 \text { and } 1365 \mathrm{mU} / / \text {, luteinising hormone } 1 \text { and } 4 \mathrm{IU} / \mathrm{l} \text {, follicle } \\
\text { stimulating hormone } 1 \text { and } 6 \mathrm{IU} / 1 \text {, thyroid stimulating hormone } 6 \cdot 4 \text { and } 20 \cdot 7 \mathrm{mU} / \mathrm{l} \text {. } \\
\text { Plasma total thyroxine } 106 \mathrm{nmol} / 1\end{array}$ & $87 \cdot 6$ & $12 \cdot 4$ \\
\hline 5 Years 0 months & & $\begin{array}{l}\text { Glucagon-propranolol test } f \text { showed cortisol } 554 \text { (basal) and } 1010 \text { (peak) nmol/l, growth } \\
\text { hormone } 8 \cdot 6 \text { and } 39 \cdot 0 \mathrm{mU} / 1 \text {, prolactin } 254 \text { and } 648 \mathrm{mU} / 1 \text {, luteinising hormone } 1 \text { and } 6 \mathrm{IU} / 1 \text {, } \\
\text { follicle stimulating hormone } 1 \text { and } 5 \mathrm{IU} / 1 \text {, thyroid stimulating hormone } 12 \cdot 4 \text { and } 62.6 \mathrm{mU} / \mathrm{l} \text {. } \\
\text { Plasma total thyroxine } 63 \mathrm{nmol} / 1 \text {. Plasma free thyroxine } 7 \cdot 8 \mathrm{pmol} / 1\end{array}$ & $91 \cdot 0$ & $12 \cdot 5$ \\
\hline 5 Years 1 month & $\begin{array}{l}\text { Normal diet reintroduced, with iodine } \\
\text { supplementation } 40 \mu \mathrm{g} \text { daily for } 4 \\
\text { weeks }\end{array}$ & & $91 \cdot 0$ & $12 \cdot 5$ \\
\hline 5 Years 2 months & & $\begin{array}{l}\text { Thyroid function tests } \ddagger \text { showed total thyroxine } 102 \mathrm{nmol} / 1 \text {, triiodothyronine } 2.4 \mathrm{nmol} / 1 \text {, free } \\
\text { thyroxine } 12 \cdot 7 \mathrm{pmol} / 1 \text {, and thyroid stimulating hormone } 4.8 \mathrm{mU} / 1 \text { (0 minutes), } 24.8 \mathrm{mU} / \mathrm{l} \\
\text { ( } 20 \text { minutes }) \text {, and } 17.9 \mathrm{mU} / 1 \text { ( }(60 \text { minutes })\end{array}$ & & \\
\hline 5 Years 3 months & & $\begin{array}{l}\text { Thyroid function tests } \ddagger \text { showed total thyroxine } 102 \mathrm{nmol} / 1 \text {, triiodothyronine } 1.8 \mathrm{nmol} / 1 \text {, free } \\
\text { thyroxine } 15 \cdot 8 \mathrm{pmol} / 1 \text {, and thyroid stimulating hormone } 2 \cdot 2 \mathrm{mU} / 1(0 \text { minutes }), 14.4 \mathrm{mU} / 1 \\
(20 \text { minutes }) \text {, and } 11.1 \mathrm{mU} / 1 \text { ( } 60 \text { minutes })\end{array}$ & $93 \cdot 0$ & $14 \cdot 0$ \\
\hline
\end{tabular}

*Insulin $0 \cdot 15 \mathrm{U} / \mathrm{kg}$ and gonadotrophin releasing hormone $100 \mu \mathrm{g}$ and thyrotrophin releasing hormone $200 \mu \mathrm{g}$ all intravenously.

tGlucagon $0.5 \mathrm{mg}$ intramuscularly and propranolol $20 \mathrm{mg}$ orally and gonadotrophin releasing hormone $100 \mu \mathrm{g}$ and thyrotrophin releasing hormone $200 \mu \mathrm{g}$ intravenously.

$\ddagger$ Thyrotrophin releasing hormone $200 \mu \mathrm{g}$ intravenously.

Reference ranges: total thyroxine $60-160 \mathrm{nmo} / 1$; free thyroxine $9-28 \mathrm{pmol} / 1$; triiodothyronine $1 \cdot 2-3 \cdot 0 \mathrm{nmol} / 1$; basal thyroid stimulating hormone $<5 \cdot 0 \mathrm{mU} / 1$; insulin-like growth factor- $1120-900 \mathrm{U} / 1$. 